\title{
Haematological Studies on Induced Hyperlipidemia and its Amelioration Using Aged Garlic Extract in Wistar Rats
}

\author{
Shashidhar Ballari ${ }^{*}$, M. L. Satyanarayana ${ }^{1}$, Suguna Rao', \\ H. D. Narayanaswamy ${ }^{1}$, Prakash Nadur $^{2}$ and V. Girishakumar ${ }^{3}$
}

${ }^{1}$ Department of Veterinary Pathology, ${ }^{3}$ Department of Veterinary Biochemistry, Veterinary

College, KVAFSU, Hebbal, Bangalore-560024, India

${ }^{2}$ Department of Veterinary Pharmacology, Veterinary College, Vinobanagar, Shimogga-577204, India

*Corresponding author

\section{A B S T R A C T}

\begin{tabular}{|l|}
\hline Ke y w o r d s \\
High fat diet, \\
Hyperlipidemia, \\
Haematology, Aged \\
garlic extract, \\
Platelet count \\
\hline Article Info \\
\hline $\begin{array}{l}\text { Accepted: } \\
\text { 25 September } 2020 \\
\text { Available Online: } \\
10 \text { October } 2020\end{array}$ \\
\hline
\end{tabular}

The effect of aged garlic extract on different haematological parameters was studied. The study included 72 Wistar albino rats were divided into 12 rats in each group. Group I served as normal control group. To group II high fat diet control was given as diet control. Rats in the group III were administered aged garlic extract at $200 \mathrm{mg} / \mathrm{kg}$ bw. Group IV rats were administered aged garlic extract at $200 \mathrm{mg} / \mathrm{kg} . \mathrm{bw}$ with high fat diet. Rats in group V were administered atorvastatin at $15 \mathrm{mg} / \mathrm{kg} . \mathrm{bw}$ with high fat diet. The group VI rats with aged garlic extract and atorvastatin at half dose $(100 \mathrm{mg}$ and $7.5 \mathrm{mg} / \mathrm{kg}$ respectively) with high fat diet. The duration of the study was for 56 days and the blood samples were collected at $42^{\text {nd }}$ and $56^{\text {th }}$ day of study for evaluation. The high fat diet induced hyperlipidemia altered haematological parameters; significant increase $(\mathrm{P}<0.05)$ in the platelet count and increased total leucocyte count. The aged garlic extract treatment showed improvements in the mean $( \pm \mathrm{SE})$ values of total erythrocyte count, haemoglobin content and moderation of platelet count was seen, this suggested that the aged garlic extract could be used for improving the high fat diet induced haematological abnormalities.

\section{Introduction}

Cardiovascular disease (CVD), which includes coronary heart disease, cerebrovascular disease, hypertension, heart failure and rheumatic heart disease, is a leading cause of death worldwide. Approximately 16.7 million or 29.2 per cent of total global deaths result from different forms of CVD every year (Ikem and Sumpio, 2011). 
The term hyperlipidemia refers to an increase in the concentration of lipids (i.e. triglycerides, cholesterol or both) in the blood (serum or plasma). More specifically, an increase in blood concentration of triglycerides is referred to as hypertriglyceridemia, while an increase in blood concentration of cholesterol is referred to as hypercholesterolemia (Xenoulis and Steiner, 2015).

Hyperlipidemia is the current medical as well as social problem, leading to increased morbidity and mortality in human beings and it is the major risk associated with atherosclerosis, which predisposes to ischemic heart disease and cerebrovascular disease (Thomas and Rich, 2007).

According to James et al., (2013) haematological parameters are associated with diagnosing and evaluating the degree and progression of certain diseases like hyperlipidemia.

All the modern drugs in use to lower blood cholesterol level, such as statins, fibrates, nicotinic acid and resins act either by inhibiting endogenous synthesis and/ or by lowering cholesterol absorption from the intestine. Owing to their side effects people are looking for safe alternatives of natural agents (Saravanan et al., 2015).

Garlic (Allium sativum) has an important dietary and medicinal role for centuries. Garlic has also been recognised since ancient times as a flavouring agent for food.

The important pharmacological effects of garlic are hypolipidemic, hypoglycaemic, anticoagulant, antihypertensive, antimicrobial, anticancer and antitumor, as an antidote for heavy metal poisoning and an immunomodulator (Lawson, 1994).
Garlic is rich source of organosulphur compounds which are responsible for its flavour, aroma and potential health benefits. Different types of garlic supplements are commercially available including garlic powders (tablets), garlic oils (capsules) and aged garlic extracts (tablets, capsules, and liquid) and each of these sources provide a different profile of organosulfur compounds having unique pharmacological actions.

Excess garlic consumption can cause toxicity, including anaemia and gastrointestinal problems. Higher concentrations of garlic extract have shown to be clastogenic in mice, which is appreciably reduced at lower concentrations (Amagase et al., 2000 and Das et al., 1996).

Extracts of fresh garlic that are aged over a prolonged period to produce aged garlic extract (AGE) contain antioxidant phytochemicals that prevent oxidant damage. These include unique water-soluble organosulfur compounds, lipid-soluble organosulfur components and flavonoids, notably allixin and selenium. AGE exerts antioxidant action by scavenging ROS, enhancing the cellular antioxidant enzymes superoxide dismutase, catalase and glutathione peroxidase, and increasing glutathione in the cells (Borek, 2001).

Atorvastatin, belongs to second generation of statins, is a synthetic reversible inhibitor of the microsomal enzyme HMG-CoA reductase. It is used in the treatment of hyperlipidemia, atherosclerosis or cardiovascular complications like coronary heart disease. Among the available HMGCoA reductase inhibitors, simvastatin and atorvastatin are the major two lipid lowering drugs used reduce the elevated lipid profiles in hyperlipidemic conditions. Statins, by inhibiting the synthesis of cholesterol, consistently reduce plasma low density 
lipoprotein (LDL)-cholesterol and total cholesterol levels (Farnier et al., 1998).

\section{Materials and Methods}

\section{Drugs and chemicals}

Aged garlic was procured from Wakunga of America Co. Ltd. USA. Atorvastatin API was procured from Microlabs India Pvt, Ltd

\section{Animals}

Normal adult Wistar albino rats weighing approximately 180-200 grams were Biogen Laboratory Animal Facility (Reg.No971/bc/06/CPCSEA) Bangalore, for conduct of the experiment for the study. They were maintained under standard laboratory conditions and fed with ad libitum standard commercial rat feed and high fat diet as per design and clean drinking water. The duration of experiment was for a period of 56 days and a prior permission was obtained from the Institutional Animal Ethics Committee (IAEC) for the conduct of the experiment.

\section{High fat diet}

To induce hyperlipidemia in the Group II, IV, $\mathrm{V}$ and VI rats, the diet prepared by adding 1 per cent of cholesterol, cholic acid 0.5 per cent and mixture of soya oil and vanaspathi ghee in the ratio of 2:3@10 ml per kg of standard rat chow diet was fed ad-libitum throughout the study period of 56 days.

\section{Experimental design}

The rats were maintained under standard laboratory conditions for a period of 15 days for acclimatization in the experimental animal house. The rats were divided, based on the body weight, into six groups with twelve rats in each group. Group I served as normal control and gavaged with distilled water. To group II was high fat diet control fed ad libitum. Group III was aged garlic extract control given at $200 \mathrm{mg} / \mathrm{kg}$ bw. Group IV aged garlic treatment group administered aged garlic extract at $200 \mathrm{mg} / \mathrm{kg}$.bw with high fat diet. Group V was atorvastatin treatment group administered atorvastatin at $15 \mathrm{mg} / \mathrm{kg}$. bw with high fat diet. The group VI was mixed treatment group administered aged garlic extract and atorvastatin at half dose (100mg and $7.5 \mathrm{mg} / \mathrm{kg}$ respectively) with high fat diet.

To study the progressive effects of the treatments given to different groups, blood samples from different groups were collected on $42^{\text {nd }}$ and $56^{\text {th }}$ day of the experiment and analysed using Mindray BC- 2800Vet auto haematology analyser. The present study aimed to investigate the possible haemorrheaological modifying effects of aged garlic extract in induced hyperlipidemia in rats.

\section{Results and Discussion}

The effect of aged garlic treatment in high fat diet induced hyperlipidemia was analysed for different haematological parameters and results are presented in table (1 to 5) and Figure (1, to 5)

In the present study, the high fat diet induced hyperlipidemia increased the total leucocyte The total erythrocyte count and total haemoglobin values were slightly low but improved at the end of the experiment. The PCV values did not show any variation and the platelet count was high on 42nd day of the study and it increased significantly $[\mathrm{P}<0.05]$ on 56th day. The slight increase in the total leucocyte count may be attributed to the inflammation induced by the high fat diet in the liver i.e steatohepatitis and hypercholesterolemia induced granulopoiesis and the reduced TEC and haemoglobin values 
may be due to reduced feed consumption as evidenced by the lower body weights in the group and simultaneous inflammatory changes, the products which may supress the erythropoiesis. Hypercholesterolemia induces granulopoiesis and enhances mobilization of the cells from bone marrow (Drechsler et al., 2010).

Hypercholesterolemia enhances serum CXCL1 levels, which promotes neutrophil mobilization via CXCR2. Hence, hyperlipidemia disturbs the tightly regulated cytokine system controlling neutrophil homeostasis at various levels and increases peripheral count (Maki et al., 2013) and also monocyte count (Swirski et al., 2007)

Hyperlipidemia is associated with increased platelet activation and underlying procoagulant state. Hyperlipidemia primes platelets and increases platelet activation in response to various agonists. Plasma cholesterol levels have a critical role in modulating platelet activity it increases platelet activation more potently than hypertriglyceridemia. Hyperlipidemia increases platelet activation via multiple mechanisms. Oxidized low-density lipoprotein or oxidized phospholipids, are increased in hyperlipidemia, they serve as ligands of platelet CD36 and activate platelets. Oxidized lipids also promote formation of procoagulant tissue factor microparticles derived from monocytes (Wang and Tall, 2016).Increase in the platelet count in the present study may be attributed to hypercholesterolemia and its many agonist actions on the platelets and its progenitor cells as explained by the Wang and Tall, 2016.

In both, aged garlic control group and aged garlic treatment group the haematological parameters did not differ from the normal control and results indicated that the mean TEC, $\mathrm{Hb}$ and PCV values improved from 42 nd to 56th day of the study indicates the positive effect of long term treatment with the AGE.

Table.1 Mean $\left( \pm\right.$ SE) values of total leucocyte count (thousands/dL) in different groups on $42^{\text {nd }}$ and $56^{\text {th }}$ day of experiment

\begin{tabular}{|l|c|c|}
\hline \multirow{2}{*}{ Groups } & \multicolumn{2}{|c|}{ Days of treatment } \\
\hline $\begin{array}{l}\text { Group I } \\
\text { (NC) }\end{array}$ & $7.45 \pm 1.24$ & $10.1 \pm 1.72$ \\
\hline $\begin{array}{l}\text { Group II } \\
\text { (DC/HFD) }\end{array}$ & $9.35 \pm 1.15$ & $10.21 \pm 2.63$ \\
\hline $\begin{array}{l}\text { Group III } \\
\text { (AGE) }\end{array}$ & $8.1 \pm 0.88$ & $12.41 \pm 1.97$ \\
\hline $\begin{array}{l}\text { Group IV } \\
\text { (HFD+AGE) }\end{array}$ & $9.76 \pm 1.05$ & $9.01 \pm 1.55$ \\
\hline $\begin{array}{l}\text { Group V } \\
\text { (HFD+ATRV) }\end{array}$ & $8.68 \pm 0.95$ & $8.8 \pm 0.95$ \\
\hline $\begin{array}{c}\text { Group VI } \\
\text { HFD } \\
+\end{array}$ \\
\begin{tabular}{c} 
(AGE+ATRV) \\
\hline
\end{tabular}
\end{tabular}

Mean \pm SE values bearing different superscript are statistically significant at $\mathrm{P} \leq 0.05$. 
Table.2 Mean $\left( \pm\right.$ SE) values of total erythrocyte count (millions/dL) in different groups on $42^{\text {nd }}$ and $56^{\text {th }}$ day of experiment

\begin{tabular}{|l|c|c|}
\hline \multirow{2}{*}{ Groups } & \multicolumn{2}{|c|}{ Days of treatment } \\
\cline { 2 - 3 } & $\mathbf{4 2}^{\text {nd }}$ & $\mathbf{5 6}^{\text {th }}$ \\
\hline $\begin{array}{l}\text { Group I } \\
\text { (NC) }\end{array}$ & $8.75 \pm 0.19$ & $9.73 \pm 0.33^{\mathrm{a}}$ \\
\hline $\begin{array}{l}\text { Group II } \\
\text { (DC/HFD) }\end{array}$ & $8.60 \pm 0.18$ & $9.49 \pm 0.09^{\mathrm{a}}$ \\
\hline $\begin{array}{l}\text { Group III } \\
\text { (AGE) }\end{array}$ & $8.07 \pm 0.48$ & $9.87 \pm 0.15^{\mathrm{a}}$ \\
\hline $\begin{array}{l}\text { Group IV } \\
\text { (HFD+AGE) }\end{array}$ & $8.16 \pm 0.22$ & $9.80 \pm 0.21^{\mathrm{a}}$ \\
\hline $\begin{array}{l}\text { Group V } \\
(\text { HFD+ATRV) }\end{array}$ & $8.40 \pm 0.24$ & $8.36 \pm 0.23^{\mathrm{b}}$ \\
\hline $\begin{array}{c}\text { Group VI } \\
\text { HFD } \\
+\end{array}$ \\
\begin{tabular}{l} 
(AGE+ATRV) \\
\hline
\end{tabular}
\end{tabular}

Mean \pm SE values bearing different superscript are statistically significant at $\mathrm{P} \leq 0.05$.

Table.3 Mean $( \pm \mathrm{SE})$ values of haemoglobin $(\mathrm{g} / \mathrm{dL})$ in different groups on $42^{\text {nd }}$ and $56^{\text {th }}$ day of experiment

\begin{tabular}{|l|c|c|}
\hline Groups & \multicolumn{2}{|c|}{ Days of treatment } \\
\cline { 2 - 3 } & $\mathbf{4 2}^{\text {nd }}$ & $\mathbf{5 6}^{\text {th }}$ \\
\hline $\begin{array}{l}\text { Group I } \\
\text { (NC) }\end{array}$ & $13.31 \pm 0.87$ & $16.2 \pm 0.57^{\mathrm{a}}$ \\
\hline $\begin{array}{l}\text { Group II } \\
\text { (DC/HFD) }\end{array}$ & $13.01 \pm 0.30$ & $15.75 \pm 0.33^{\mathrm{a}}$ \\
\hline $\begin{array}{l}\text { Group III } \\
\text { (AGE) }\end{array}$ & $12.38 \pm 0.95$ & $16.03 \pm 0.30^{\mathrm{a}}$ \\
\hline $\begin{array}{l}\text { Group IV } \\
\text { (HFD+AGE) }\end{array}$ & $12.26 \pm 0.18$ & $15.7 \pm 0.41^{\mathrm{a}}$ \\
\hline $\begin{array}{l}\text { Group V } \\
\text { (HFD+ATRV) }\end{array}$ & $12.58 \pm 0.33$ & $12.65 \pm 0.36^{\mathrm{b}}$ \\
\hline $\begin{array}{c}\text { Group VI } \\
\text { HFD } \\
+\end{array}$ \\
$\begin{array}{c}\text { (AGE+ATRV) } \\
\text { (HE) }\end{array}$ & $13.16 \pm 0.31$ & $12.83 \pm 0.23^{\mathrm{b}}$ \\
\hline
\end{tabular}

Mean \pm SE values bearing different superscript are statistically significant at $\mathrm{P} \leq 0.05$. 
Table.4 Mean $( \pm \mathrm{SE})$ values of packed cell volume (PCV) $(\%)$ in different groups on $42^{\text {nd }}$ and $56^{\text {th }}$ day of experiment

\begin{tabular}{|l|c|c|}
\hline \multirow{2}{*}{ Groups } & \multicolumn{2}{|c|}{ Days of treatment } \\
\cline { 2 - 3 } & $\mathbf{4 2}^{\text {nd }}$ & $\mathbf{5 6}^{\text {th }}$ \\
\hline $\begin{array}{l}\text { Group I } \\
\text { NC) }\end{array}$ & $49.55 \pm 1.14$ & $50.68 \pm 1.36$ \\
\hline $\begin{array}{l}\text { Group II } \\
\text { (DC/HFD) }\end{array}$ & $49.13 \pm 0.70$ & $48.68 \pm 1.09$ \\
\hline $\begin{array}{l}\text { Group III } \\
\text { (AGE) }\end{array}$ & $47.38 \pm 2.85$ & $50.7 \pm 0.78$ \\
\hline $\begin{array}{l}\text { Group IV } \\
\text { (HFD+AGE) }\end{array}$ & $46.86 \pm 0.61$ & $50.43 \pm 1.48$ \\
\hline $\begin{array}{l}\text { Group V } \\
\text { (HFD+ATRV) }\end{array}$ & $45.96 \pm 0.99$ & $46.2 \pm 0.96$ \\
\hline $\begin{array}{c}\text { Group VI } \\
\text { HFD } \\
+\end{array}$ \\
\begin{tabular}{c} 
(AGE+ATRV) \\
\hline
\end{tabular}
\end{tabular}

Mean \pm SE values bearing different superscript are statistically significant at $\mathrm{P} \leq 0.05$.

Table.5 Mean $\left( \pm\right.$ SE) values of platelet count (billion/L) in different groups on $42^{\text {nd }}$ and $56^{\text {th }}$ day of experiment

\begin{tabular}{|l|c|c|}
\hline \multirow{2}{*}{ Groups } & \multicolumn{2}{|c|}{ Days of treatment } \\
\cline { 2 - 3 } & $\mathbf{4 2}^{\text {nd }}$ & $\mathbf{5 6}^{\text {th }}$ \\
\hline $\begin{array}{l}\text { Group I } \\
\text { (NC) }\end{array}$ & $527.16 \pm 65.70$ & $911.66 \pm 77.03^{\mathrm{b}}$ \\
\hline $\begin{array}{l}\text { Group II } \\
\text { (DC/HFD) }\end{array}$ & $683.5 \pm 23.15$ & $1176.16 \pm 96.21^{\mathrm{a}}$ \\
\hline $\begin{array}{l}\text { Group III } \\
\text { (AGE) }\end{array}$ & $601 \pm 36.48$ & $755 \pm 42.44^{\mathrm{bc}}$ \\
\hline $\begin{array}{l}\text { Group IV } \\
\text { (HFD+AGE) }\end{array}$ & $640.5 \pm 28.92$ & $977.16 \pm 33.85^{\mathrm{ab}}$ \\
\hline $\begin{array}{l}\text { Group V } \\
\text { (HFD+ATRV) }\end{array}$ & $606.83 \pm 29.54$ & $628.83 \pm 28.19^{\mathrm{c}}$ \\
\hline $\begin{array}{c}\text { Group VI } \\
\text { HFD } \\
+\end{array}$ \\
\begin{tabular}{c} 
(AGE+ATRV) \\
\hline
\end{tabular}
\end{tabular}

Mean \pm SE values bearing different superscript are statistically significant at $\mathrm{P} \leq 0.05$. 
Fig.1 Mean $( \pm S E)$ total leucocyte count (thousands per decilitre) (TLC) values of in various groups on $42^{\text {nd }}$ and $56^{\text {th }}$ day of the experiment

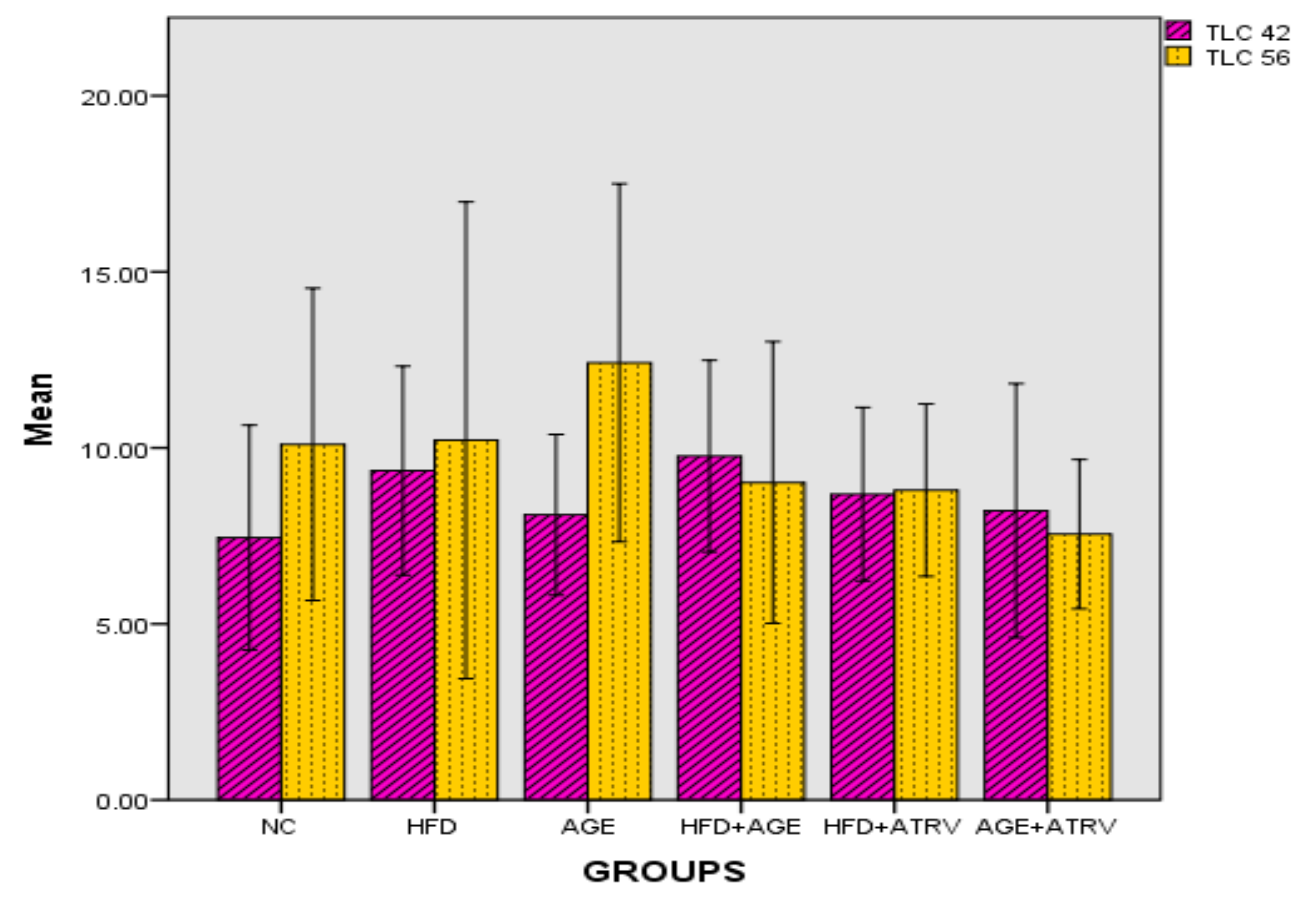

Error Bars: $95 \% \mathrm{Cl}$

Fig.2 Mean $( \pm$ SE) total red blood cell count (RBC) (millions per decilitre) values of in various groups on $42^{\text {nd }}$ and $56^{\text {th }}$ day of the experiment

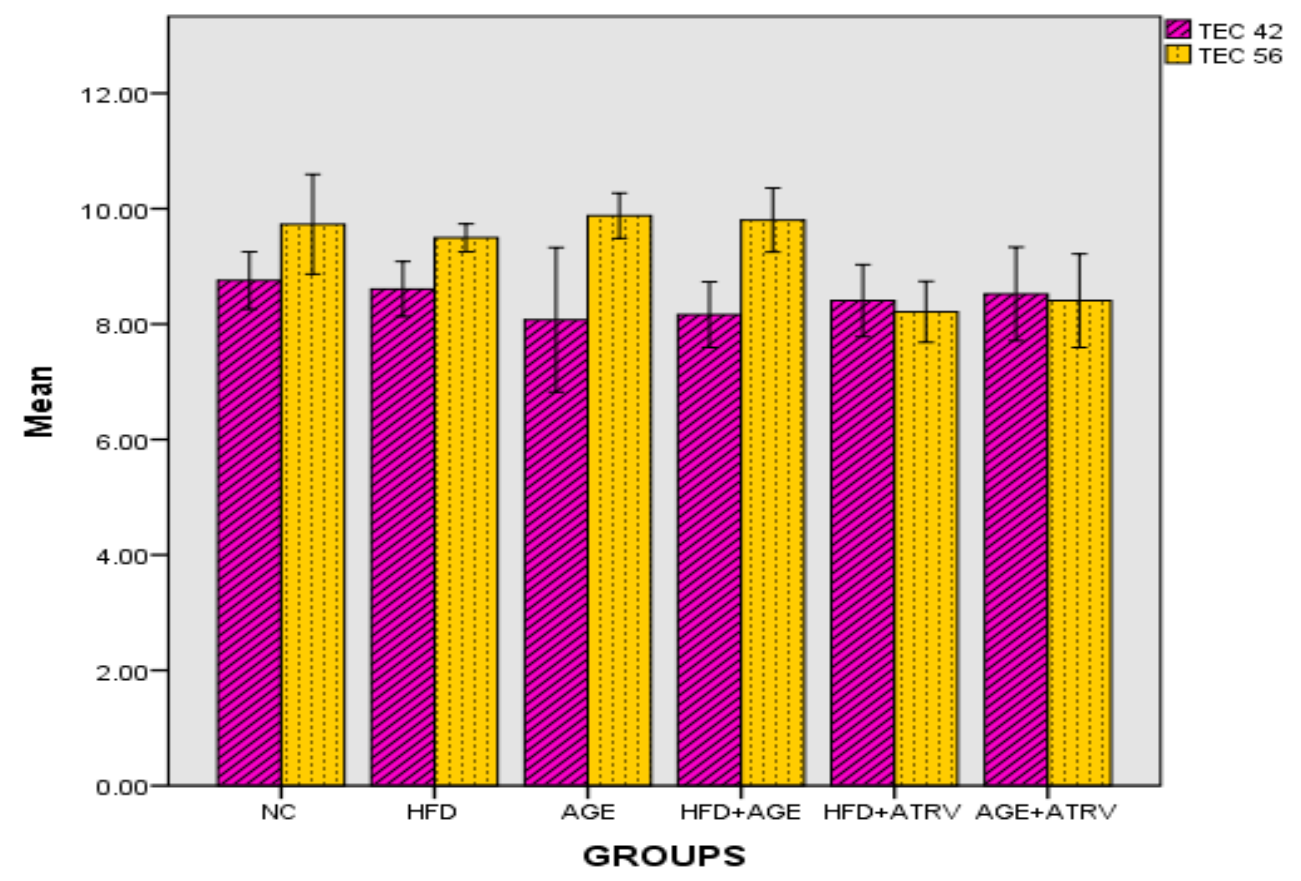

Error Bars: $95 \% \mathrm{Cl}$ 
Fig.3 Mean $\left( \pm\right.$ SE) total haemoglobin $(\mathrm{Hb})$ (grams per decilitre) values of various groups on $42^{\text {nd }}$ and $56^{\text {th }}$ day of the experiment

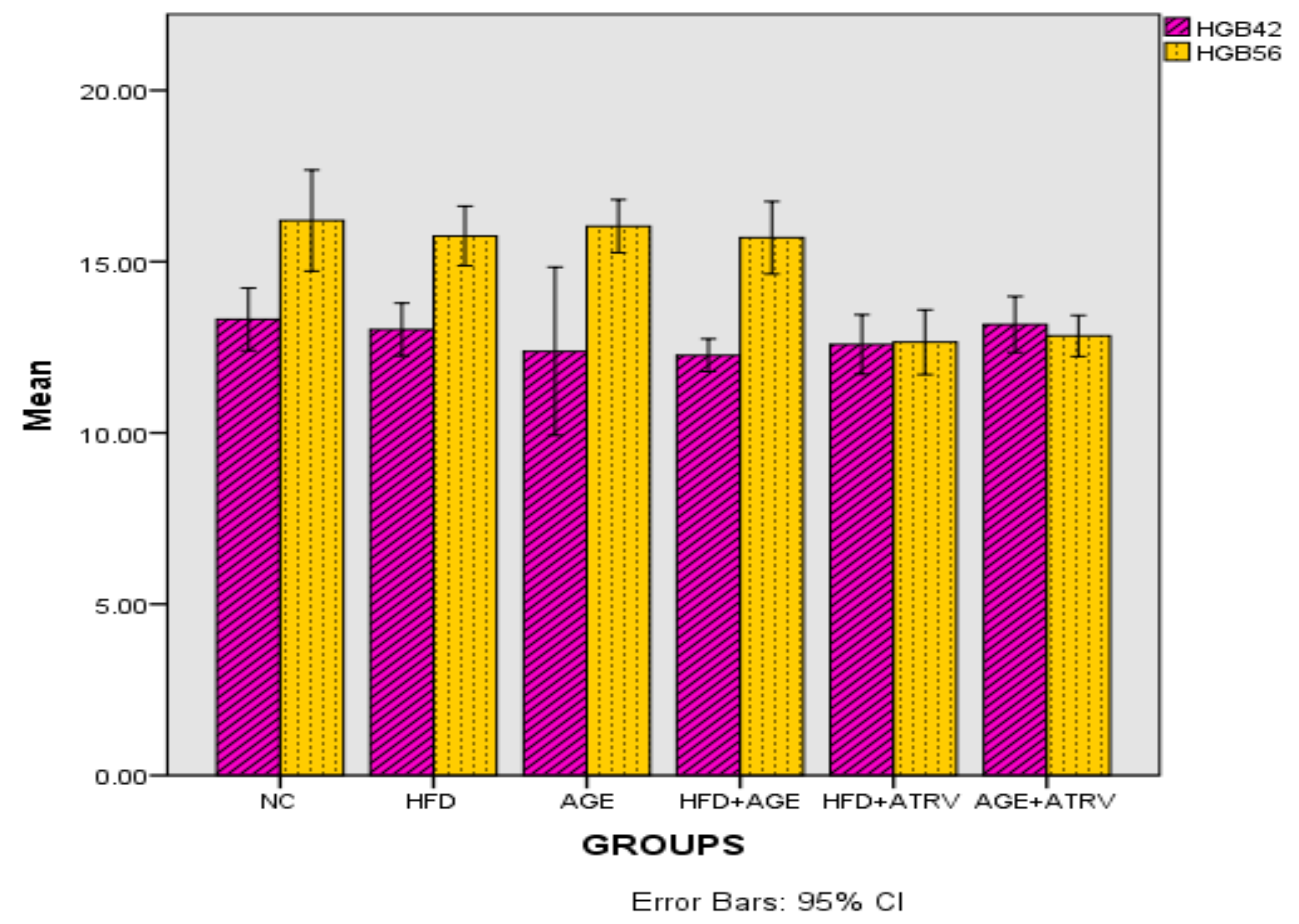

Fig.4 Mean $\left( \pm\right.$ SE) packed cell volume $(\%)$ values of various groups on $42^{\text {nd }}$ and $56^{\text {th }}$ day of the experiment

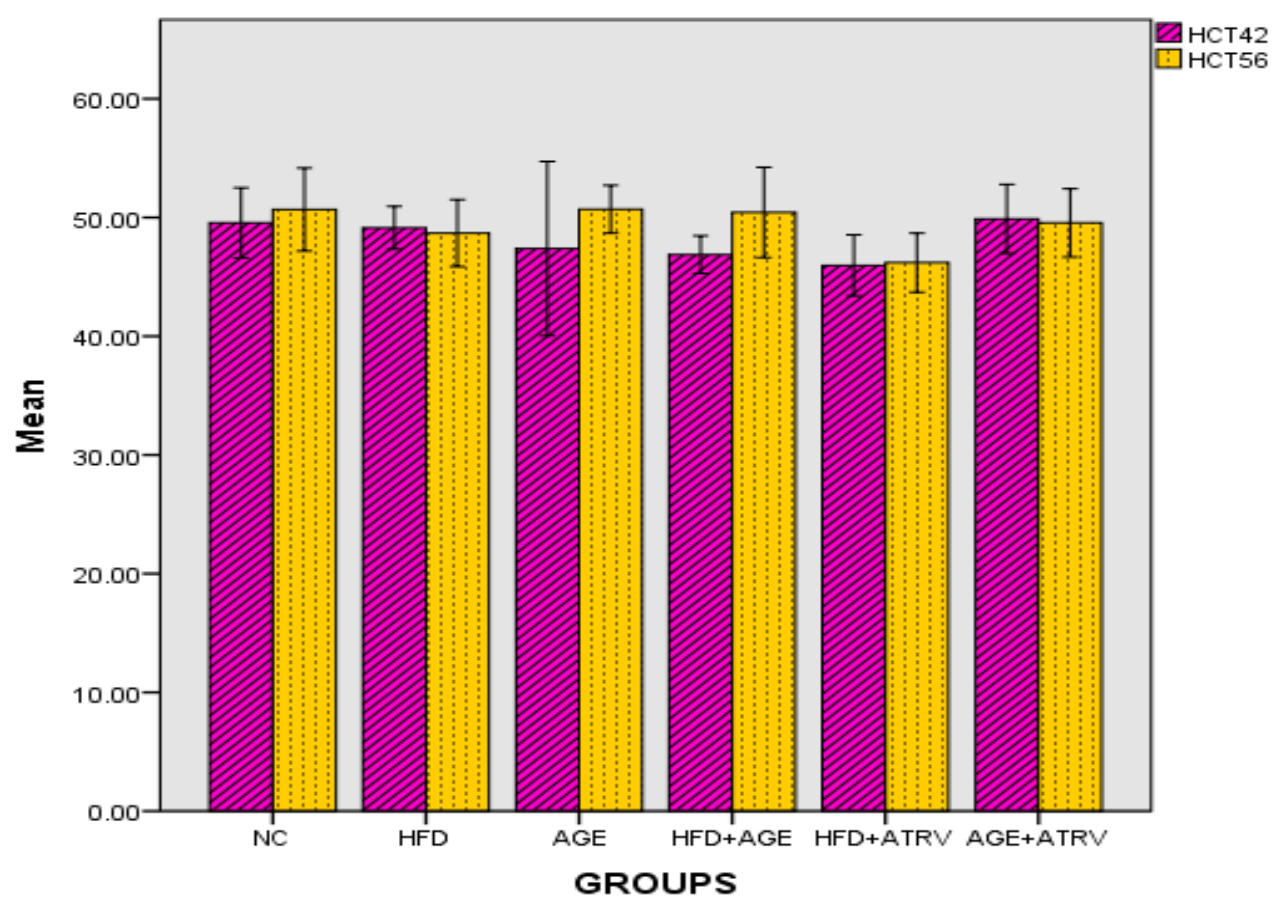

Error Bars: $95 \% \mathrm{Cl}$ 
Fig.5 Mean $\left( \pm\right.$ SE) platelet count (billion per litre) values of various groups on $42^{\text {nd }}$ and $56^{\text {th }}$ day of the experiment

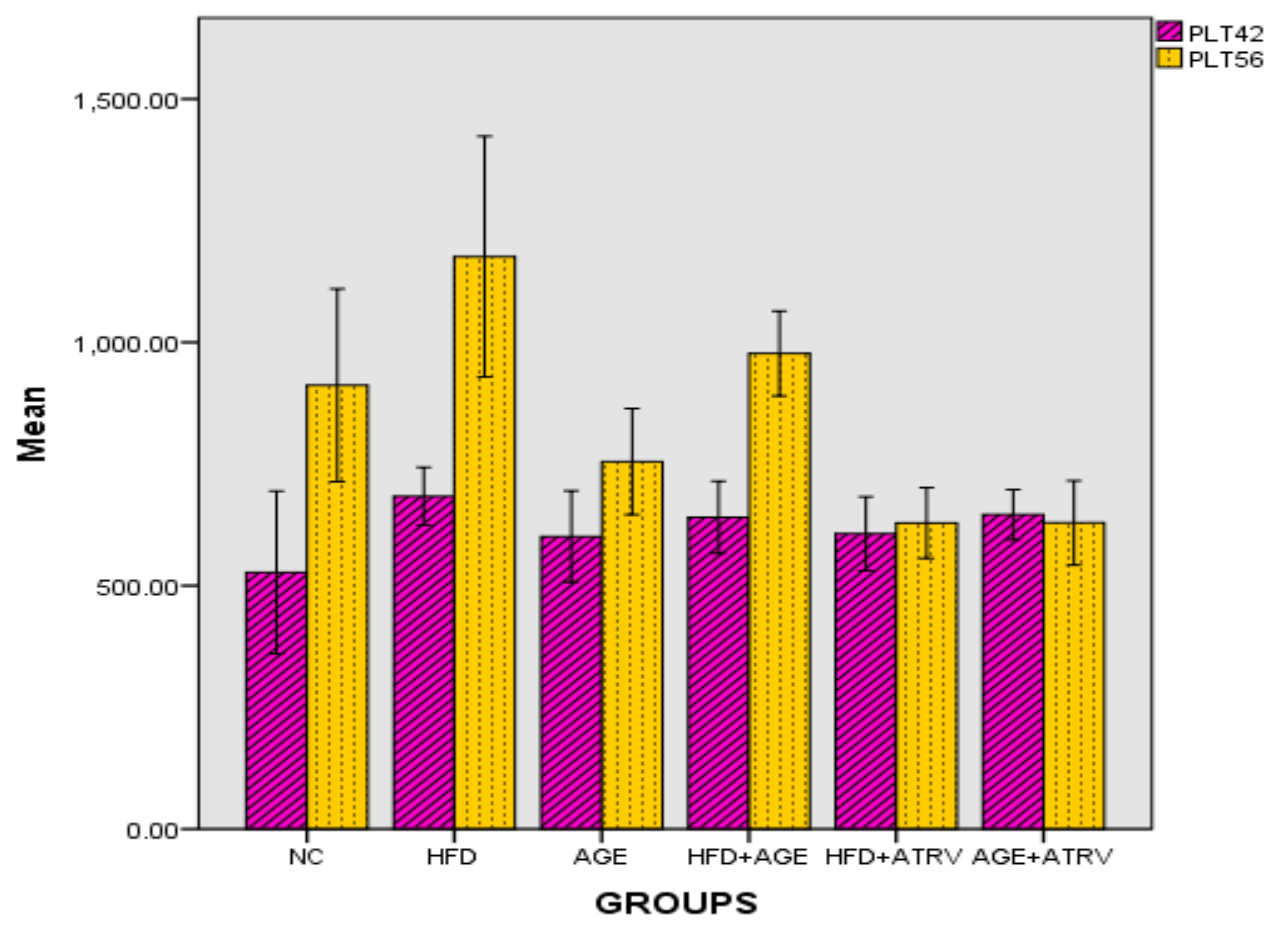

Error Bars: $95 \% \mathrm{Cl}$

Aged garlic extract extract (AGE) and its constituents inhibits platelet aggregation in a concentration-dependent manner by working in a synergistically and exerting multiple effects on biochemical pathways. Calcium movement from/into the cells is the key mechanism (Steiner et al., 1996a).

In the Atorvastatin treatment group the mean total erythrocyte, haemoglobin and PCV values were comparable to normal control on 42nd day but there was a significant decrease in the mean TEC values on 56th day of the experiment which could be partly attributed to the continued triglyceridemia, mild steatohepatitis in the atorvastatin treatment group. Similar observations were made in respect of TEC, $\mathrm{Hb}$ and platelet count in mixed treatment group.

In conclusion, the study highlighted the beneficial effects of aged garlic extract at
$200 \mathrm{mg} / \mathrm{kg}$ bw in improving the haematological parameters in induced hyperlipidemia in Wistar rats and possible roles of AGE in improving the blood parameters.

\section{Acknowledgements}

Authors are thankful to the Head of the Department, Department of Veterinary pathology and Dean, Veterinary College, Bangalore, for providing facilities to carry out the present study.

\section{References}

Amagase, H., Moriguchi, T. and Kasuga, S., 2000. Comparison of oxidative damage of garlic preparation including entericcoated garlic powder preparation and allicin-derived compounds on erythrocyte and duodenum. 
Phytomedicine, 8: 118-132.

Borek, C., 2001. Antioxidant health effects of aged garlic extract. The Journal of nutrition, 131(3): 1010-1015.

Das, T., Choudhury, A.R., Sharma, A. and Talukder, G., 1996. Effects of crude garlic extract on mouse chromosomes in vivo. Food and chemical toxicology, 34(1): 43-47

Drechsler, M., Megens, R.T., Van Zandvoort, M., Weber, C. and Soehnlein, O., 2010. Hyperlipidemia-triggered neutrophilia promotes early atherosclerosis. Circulation, 122(18): 1837-1845.

Farnier, M. and Davignon, J., 1998. Current and future treatment of hyperlipidemia: the role of statins. The American journal of cardiology,82(4):.3-10.

Ikem, I. and Sumpio, B.E., 2011. Cardiovascular disease: the new epidemic in sub-Saharan Africa. Vascular, 19(6): 301-307.

James, D.B., Adejor, E.B., Ameh, D.A., Kadejo, A.O. and OLABA, T., 2013. Preventive and therapeutic effects of Garcinia kola biflavonoid fractions on some haematological parameters of P407 induced hyperlipidemic albino rats. Journal of Natural Remedies, 14(1):.41-47

Lawson LD. Bioactive Organosulfur Compounds of Garlic and Garlic
Product, In: Kinghorn AD and Balandrin MF, editors. Human medicinal agents from plants. American Chemical Society, Washington DC, 1994., Pp. 306-330.

Steiner, M., Khan, A.H., Holbert, D. and Lin, R.I., 1996.A double-blind crossover study in moderately hypercholesterolemic men that compared the effect of aged garlic extract and placebo administration on blood lipids. Am J. Clin. Nutr., 64(6): 866-870.

Swirski FK, Libby P, Aikawa E, Alcaide P, Luscinskas FW, Weissleder R and Pittet MJ. 2007. Ly-6 Chi monocytes dominate hypercholesterolemia associated monocytosis and give rise to macrophages in atheromata. J Clin Investigtion., 117(1):195-205.

Thomas, S. and Rich, M.W., 2007. Epidemiology, pathophysiology, and prognosis of heart failure in the elderly. Heart Failure Clinics, 3(4): 381-387.

Wang, N. and Tall, A.R., 2016. Cholesterol in platelet biogenesis and activation. Blood, $J$ Am Soc Hematol, 127(16):1949-1953.

Xenoulis, P.G. and Steiner, J.M., 2015. Canine hyperlipidaemia. Journal of Small Animal Practice, 56(10): 595605.

\section{How to cite this article:}

Shashidhar Ballari, M.L. Satyanarayana, Suguna Rao, H.D. Narayanaswamy, Prakash Nadur and Girishakumar, V. 2020. Haematological Studies on Induced Hyperlipidemia and Its Amelioration Using Aged Garlic Extract in Wistar Rats. Int.J.Curr.Microbiol.App.Sci. 9(10): 3837-3846. doi: https://doi.org/10.20546/ijcmas.2020.910.441 